\title{
Technology Use, Technology Views: Anticipating ICT Use for Beginning Physical and Health Education Teachers
}

\author{
Lori Lockyer and John Patterson \\ University of Wollongong, Wollongong, Australia
}

llockyer@uow.edu.au patto@uow.edu.au

\begin{abstract}
In Australia, the national initiative known as Learning in an Online World, focuses school jurisdictions across the country meet the challenge of achieving the national vision of all schools "... confidently using ICT in their everyday practices to improve learning, teaching and administration" (MCEETYA, 2005, p. 3). One strategy in reaching this goal is the effective preparation of pre-service teachers to use and integrate technology in their teaching and learning practices.

This article reports on a research study that aimed to explore the issue preparation for use of technology in teaching by understanding the current and anticipated technology usage for Australian health and physical education pre-service teachers.
\end{abstract}

Keywords: ICT education in teacher preparation, survey research, technology usage

\section{Introduction}

Concern is often expressed about the efficacy of pre-service teacher education programs to prepare teachers to use technologies in their practice (Kirschner \& Sellinger, 2003; Pearson, 2003). The research study presented in this article suggests that a well-planned, integrated approach to technology use can have a potential positive impact on the technology practices by teachers in classroom and professionally related activity.

This article reports on perceptions of pre-service teachers in the specific discipline of health and physical education (H/PE). It addresses their use of information and communication technologies (ICT) in their teacher training and their perceived use of ICT in their future teaching experiences. To meet the goal of widespread adoption of ICT in the K-12 education context, the efficacy of pre-service teacher education programs has been determined as being paramount. The data from the study provides insights as to the effectiveness of a pre-service education program in the preparation of future teachers.

Material published as part of this publication, either on-line or in print, is copyrighted by the Informing Science Institute. Permission to make digital or paper copy of part or all of these works for personal or classroom use is granted without fee provided that the copies are not made or distributed for profit or commercial advantage AND that copies 1) bear this notice in full and 2) give the full citation on the first page. It is permissible to abstract these works so long as credit is given. To copy in all other cases or to republish or to post on a server or to redistribute to lists requires specific permission and payment of a fee. Contact Publisher@InformingScience.org to request redistribution permission.
It has been argued that, within teacher education programs, ICT must be integrated with curriculum, pedagogy and field experience to model what the preservice teacher might use in their own practice (Willis and Mehlinger, 1996). As noted by Vongalis Macrow, Wright and Brew (2004), it is critical to focus on the integration aspect of ICT preparation. That is, how ICT can pedagogically support a particular discipline area. 
Within the broad areas of sport, physical activity and health, technologies are widely used as educational tools; to collect data as a basis for the development of better coaching methods and performance techniques; for health problem diagnosis; and, a myriad of other functions. It is not unreasonable to assume therefore, that future teachers of health and physical education would be exposed to ICT in the broad domain of their discipline area and be interested in technologies as educational tools.

Many H/PE teachers have been among the early adopters for sharing discipline-based teaching resources online (e.g., through online clearinghouses such as PE Central

(http://www.pecentral.org) in the US and ActiveHealth (http://www.activehealth.uow.edu.au/) in Australia. Yet, while investigating how US pre-service physical educators feel about their preparation to integrate technology effectively in their professional careers, Liang, Walls, Hicks, Clayton, and Yang (2006) found participants did not feel they were fluent (skilled) nor confident users of IT. Lack of confidence and fluency is a function of lack of expertise and experience - two issues which can be addressed in pre-service teacher education programs. These two issues compound feelings of inadequacy and uncertainty as to how best to use ICT pedagogy in a teaching environment.

Given the seeming rich use of technologies in the broad domain of health and physical education, and therefore assumed high levels of awareness of use of such technologies by physical and health education pre-service teachers, it was appropriate to explore current and anticipated usage of technology of a cohort of graduating pre-service teachers. It could be reasonably expected that, at the end of a four year professional preparation course, they would be using a range of technology tools and foresee the use of those tools in their professional role would increase.

\section{Method}

A survey design was implemented in an attempt to understand the technology-related practices and anticipated professional use of technology of the study participants. The study population involved an available sample comprised of a cohort of graduating pre-service health and physical education teachers. In terms of context, this particular cohort of students had engaged in a fouryear health and physical education teacher preparation program with a focus on educational theory, child development, discipline-based content and curriculum, methods, and classroom management. This teacher preparation program includes a number of school-based practical experiences culminating in a five-week block practicum in the middle of the final year. The final year of the program also includes a subject particularly focused on teacher professionalism and provides the pre-service teachers an opportunity to articulate, in written and oral form, how they seem themselves in their future role as teacher.

Like most pre-service teacher education programs in Australia, the program includes as specific ICT in education subject that covers basic skills such as word processing and presentation applications. However, given the nature of the discipline, examples and opportunities to employ varied computer-based tools are provided through other subject offerings. Also, web-based resources and readings are available through a learning management system to support their course subjects.

This cohort did experience some unique technology-based initiatives including using interactive technologies as a pedagogical tool; engagement in online collaborative tutorials in a first-year health education subject; and, the opportunity to engage as an online mentor thus using webbased communication tools for discussion and professional development.

The survey instrument covered issues of competence and confidence of using a computer generally, frequency of use of a range of computer and Internet applications for academic purposes, anticipated frequency of use of the range of applications in their future teaching role; and, percep- 
tion of the usefulness of the Internet to support their teaching needs. Experts in both teacher education and educational technology tested the instrument for content validity. The resulting instrument was then pilot tested with a sample of pre-service teachers enrolled in a compatible course.

The survey was administered to participants during the final class meeting of the cohort's final academic year. Potential participants were requested to volunteer to complete the survey. A response rate of $84 \%$ was achieved as 38 of the 45 graduating pre-service teachers completed the survey. Descriptive analyses were performed on all items. During analysis, response categories for items focused on current frequency of use and anticipated frequency of use for computer and Internet applications were collapsed such that 'daily' and 'several times per week' were combined to be reported as 'frequently'; 'weekly' and 'monthly' were combined and as reported as 'sometimes'; and, 'rarely' and 'never' were combined and reported as 'rarely.' Chi Square (Siegel, 1956) was performed on relevant variables in order to ascertain the strength of perceived change from current use to anticipated use of technologies.

\section{Results}

Of the 38 participants, 17 were male and 21 were female. The majority $(n=29)$ of respondents rated their computer knowledge as very high or high. All but one respondent felt comfortable or very comfortable about using a computer for personal purposes. Most respondents $(n=22)$ noted that they were using the Internet daily or several times per week.

In terms of their use of technologies for academic purposes (current use), frequencies of responses are reported in Table 1.

Table 1: Response category counts for technology use for academic purposes

\begin{tabular}{|l|c|c|c|c|}
\hline & $\underline{N}$ & $\begin{array}{c}\text { Fre- } \\
\text { quently }\end{array}$ & $\begin{array}{c}\text { Some- } \\
\text { times }\end{array}$ & Rarely \\
\hline Word processing & 38 & 24 & 14 & 0 \\
\hline Spreadsheet & 38 & 2 & 17 & 19 \\
\hline Database & 37 & 1 & 22 & 14 \\
\hline Desktop publishing & 38 & 5 & 15 & 18 \\
\hline Presentation & 37 & 2 & 14 & 21 \\
\hline Paint/draw & 36 & 0 & 6 & 30 \\
\hline Graphics creation & 36 & 1 & 4 & 31 \\
\hline Multimedia development & 37 & 0 & 3 & 34 \\
\hline Web page/site development & 37 & 2 & 2 & 33 \\
\hline Send and receive email & 37 & 28 & 7 & 2 \\
\hline Communicate in chat spaces or discussion forums & 38 & 4 & 5 & 29 \\
\hline Connect to networked computer servers & 37 & 3 & 6 & 28 \\
\hline Browse the Web & 38 & 18 & 18 & 2 \\
\hline Search for Web sites about a particular topic & 38 & 18 & 20 & 0 \\
\hline Access Web sites when provided with address & 38 & 16 & 18 & 4 \\
\hline
\end{tabular}

Note: Frequently = daily or several times per week; Sometimes = weekly or monthly; Rarely = rarely or never 
The pre-service health and physical education teachers who participated in this study were frequent users of word processing (24), email (28) and web browsing $(n=18)$ and searching $(n=18)$. They sometimes used other productivity-type computer applications such as spreadsheets $(n=17)$, and databases $(\mathrm{n}=22)$ but rarely used more creative applications such as drawing or graphics creation software or multimedia and web development tools. Presentation software (such as PowerPoint) was the only creative tool that was used sometimes $(n=14)$. Given the opportunities available to this cohort of pre-service teachers for engaging in online collaborative tutorials and acting as online mentors to less experienced peers, it is interesting to see infrequent use of chat spaces and discussion forums.

The distribution of anticipated use of technologies in their teaching role is provided in Table 2.

\begin{tabular}{|l|c|c|c|c|}
\hline \multicolumn{5}{|c|}{ Table 2: Response category counts for anticipated technology use in teaching role } \\
\hline & $\underline{N}$ & $\begin{array}{c}\text { Fre- } \\
\text { quently }\end{array}$ & $\begin{array}{c}\text { Some- } \\
\text { times }\end{array}$ & Rarely \\
\hline Word processing & 36 & 29 & 7 & 0 \\
\hline Spreadsheet & 36 & 14 & 18 & 4 \\
\hline Database & 33 & 9 & 21 & 3 \\
\hline Desktop publishing & 34 & 8 & 14 & 12 \\
\hline Presentation & 35 & 7 & 24 & 4 \\
\hline Paint/draw & 33 & 3 & 12 & 18 \\
\hline Graphics creation & 33 & 2 & 15 & 16 \\
\hline Multimedia development & 33 & 2 & 11 & 20 \\
\hline Web page/site development & 32 & 4 & 10 & 18 \\
\hline Send and receive email & 35 & 25 & 10 & 0 \\
\hline Communicate chat spaces or discussion forums & 33 & 3 & 12 & 18 \\
\hline Connect to networked computer servers & 32 & 3 & 12 & 17 \\
\hline Browse the Web & 34 & 19 & 14 & 1 \\
\hline Search for Web sites about a particular topic & 35 & 21 & 14 & 0 \\
\hline Access Web sites when provided with the address & 35 & 23 & 11 & 1 \\
\hline Note: Frequently = daily or several times per week; Sometimes = weekly or monthly; Rarely = rarely or \\
\hline never
\end{tabular}

Sixty five percent or greater of respondents indicated that they would make use of word processing, email technologies, web searching tools, and specific web sites in their teaching activity on a frequent basis. Greater than $60 \%$ said they would use spreadsheets, databases, desktop publishing, graphics creation, on a sometime to frequent basis. Interestingly, more than $45 \%$ indicated similar patterns of use for chat spaces and discussion forums as well as sophisticated ICT practices such as multimedia and web development. The results presented in Table 2 superficially demonstrated potential shifts in understandings of the use of technologies in the educational process (a desired outcome of the teacher education program). This anticipated use was considered against self-reported current use using Chi Square to see if there was any significant difference between current behavior and anticipated future behavior. Chi Square was performed to test the null hypothesis of no change. A significant Chi Square ( $\mathrm{p}=0.05$ or better) was found between current use and anticipated use in teaching for spreadsheets, databases, graphics creation, multi- 
media development, and web page development. With the exception of spreadsheets, the perceived future use of these generally complex technologies indicates an understanding of their role in the educational domain and a confidence to embrace them as pedagogical tools.

\section{Discussion and Conclusion}

The four-year program of study at this institution has two foci for the understanding and mastering of ICT for pre-service teachers in a professional course of study. Conceptual understanding of and practical skill development in ICT are specifically presented in a focused subject but are also integrated throughout other subjects in the course. Therefore the students are given specific knowledge and experiences to improve understanding and skill sets. This is reinforced tangentially in other subjects by way of assessment tasks or exposure to use in the professional domain.

The results of this study suggest that this approach may have strength as beginning H/PE teachers see a place for ICT in their role. They anticipate using some of computer applications daily or several times per week. They expect to use a number of Internet applications frequently and overwhelming report a perception that the Internet will be useful for their teaching needs. The findings presented here mirror the perspective of British PE teachers. As reported by Thomas and Stratton (2006), a majority of the $252 \mathrm{PE}$ teachers surveyed felt that ICT were valuable teaching tools.

The findings suggests that this pre-service teacher education program is, at minimum, reaching its goal for students using and anticipating use of the 'basic tools of the trade.' But, more importantly it may be considered that the program helps to contribute to an appreciation of the more sophisticated tools that might support teaching and learning.

The results also support the need for integration of technology tools and resources in teacher preparation program. The strength of perceived change from current use to anticipated use of technologies in future teaching role supports notions of modeling and practicing ICT integration. This is consistent with the findings of Kimbell-Lopez, LaBorde, and LeBoeuf-Davis (2006) who noted and increase of technology competence scores for pre-service teachers who used technology resources in their physical education methods assignments.

For some computer and Internet applications, usage increased over the course of their final academic year. In future studies it would be interesting to explore if there is any relationship increased usage and exposure to and experience with the use of ICT during the final five-week block practicum. While not including the discipline of health and physical education, Cuckle and Clarke (2002) found variable results when exploring the relationship between pre-service teacher competence and use of ICT and use of technology in teaching by teacher-mentors in the practicum situation. Taking this focus on practical experience further, it would be interesting to understand how perceived and actual access to ICT infrastructure in schools relates to use and competency. This is an issue highlighted in British studies (Cuckle \& Clark, 2002; Thomas \& Stratton, 2006) and anecdotally alluded to by Australian H/PE teachers and pre-service teachers.

The findings of this and related studies fit within the context of the broader education environment where more widespread adoption of ICT in teaching is being mandated. Such strategies for this mandate are the roll of network and computer infrastructure in schools, the development of electronic resources (or learning objects) that are Internet accessible, and pedagogical and curriculum policies that call for the integration of technology into the teaching and learning experience. In Australia, the Ministerial Council on Education Employment Training and Youth Affairs (1999) in their The Adelaide Declaration on National Goals for Schooling in the Twenty-first Century included a focus on ICT by stating that when students leave school they should be "...confident, creative and productive users of new technologies, particularly information and communication technologies, and understand the impact of those technologies on society [Goal 
1.6]." Following these goals statements, the Council initiated series of policy, strategy, framework and action plan documents, known as Learning in an Online World, to help the school jurisdictions across the country meet the challenge of achieving the national vision of all schools "... confidently using ICT in their everyday practices to improve learning, teaching and administration" (MCEETYA, 2005, p. 3).

\section{References}

Cuckle, P., \& Clarke, S. (2002). Mentoring student-teachers in schools: Views, practices and access to ICT. Journal of Computer Assisted Learning, 18, 330-340.

Kimbell-Lopez, K., LaBorde, C. \& LeBoeuf-Davis, D. (2006). Investigating teacher candidate's use of technology in methods coursework. In C. Crawford et al. (Eds.), Proceedings of Society for Information Technology and Teacher Education International Conference 2006 (pp. 3895-3899). Chesapeake, VA: AACE.

Kirschner, P. \& Sellinger, M. (2003). The state of affairs of teacher education with respect to information and communications technology. Technology, Pedagogy and Education, 12(1), 5-17.

Liang, G., Walls, R., Hicks, V., Clayton, L. \& Yang, L. (2006). Will tomorrow's physical educators be prepared to teach in the digital age? Contemporary Issues in Technology and Teacher Education, 6 (1), $143-156$

Ministerial Council on Education Employment Training and Youth Affairs (MCEETYA). (1999). The Adelaide Declaration on National Goals for Schooling in the Twenty-first Century. Retrieved 10 September, 2006, from

http://www.dest.gov.au/sectors/school_education/policy_initiatives_reviews/national_goals_for_schoo ling in the twenty first century.htm

Ministerial Council on Education Employment Training and Youth Affairs (MCEETYA). (2005). Contemporary Learning: learning in an online world. Retrieved 13 December 2006, 2006, from http://icttaskforce.edna.edu.au/icttaskforce/webdav/site/icttaskforcesite/users/root/public/learning_onli ne contemp.pdf

Pearson, J. (2003). Information and communications technologies and teacher education in Australia. Technology, Pedagogy and Education, 12(1), 39-58.

Siegel, S. (1956). Nonparametric statistics for the behavioral sciences. McGraw-Hill Kogakusha.

Thomas, A., \& Stratton, G. (2006). What we are really doing with ICT in physical education: A national audit of equipment, use, teacher attitudes, support, and training. British Journal of Educational Technology, 37(4), 617-632.

Vongalis Macrow, A., Wright, P., \& Brew, C. (2004). Integrating ICT in pre-service teacher education Reframing teacher education. Paper presented at the Australian Association for Research in Education, Melbourne.

Willis, J. W., \& Mehlinger, H. D. (1996). Information technology and teacher education. In J. Sikula, T. J. Buttery, \& E. Guyton (Eds.), Handbook of research on teacher education (2nd ed., pp. 978-1029). New York: Simon \& Schuster Macmillan. 


\section{Biographies}

Associate Professor Lori Lockyer teaches in the ICTs for Learning program in the Faculty of Education at the University of Wollongong, Australia. Lori's research interests focus on the use of ICTs in K-12 education, for professional education, and for health education and heath service initiatives. Among Lori's current projects is Making News Today

(http://makingnewstoday.uow.edu.au/) which investigates how learners develop multiliteracies through their involvement in the creation of digital video news.

Professor John Patterson Is Deputy Vice Chancellor (Operations) at the University of Wollongong, Australia. John's teaching and research activities focus on physical and health education, educational policy development and information technology in education. Formally a physical education teacher, teacher educator and Dean of Education, John has helped to lead change across all education sectors in Australia. 